\title{
Heat Stress and Body Temperature in Brown Swiss Cows Raised in Semi-Arid Climate of Ceará State, Brazil
}

\author{
Jaqueline Silva Leles ${ }^{1}$, Inti Campos Salles Rodrigues', Maurício Francisco Vieira Neto', \\ Aderson Martins Viana Neto ${ }^{2}$, David Ramos da Rocha ${ }^{3}$, Antônio Nelson Lima da Costa ${ }^{4}$, \\ Maria Gorete Flores Salles ${ }^{5}$ \& Airton Alencar de Araújo ${ }^{1}$
}

\begin{abstract}
Background: In tropical countries like Brazil, air temperature and relative humidity have a significant effect on animal physiology; there is a great impact of solar radiation on physiological parameters, especially on body temperature. This study evaluated the occurrence of heat stress in Brown Swiss cows in a tropical semi-arid climate, and checked for the correlation between internal body temperatures [rectal temperature (RT) and vaginal temperature (VT)] with surface temperature (ST) to determine if these variables are associated.

Materials, Methods \& Results: Twenty-eight Brown Swiss cows at three stages of the lactation cycle were used in this study: 10 nonpregant lactating (NPL) cows, 8 dry pregnant (DP) cows, and 10 pregnant lactating (PL) cows. These animals were between the second and third calving, weighed between 346 and $720 \mathrm{~kg}$, and had ages between 2 and 13 years. During the experimental period, air temperature and relative humidity $(\mathrm{RH})$ at the experimental site were measured using a digital thermohygrometer. The temperature and humidity index (THI) was calculated according to methodology described by Thom (1958), and was used as an environmental comfort parameter. For the evaluation of RT and VT, two digital clinical thermometers, one inserted in the vagina and the other in the rectum, were used simultaneously to minimize stress. Surface temperature (ST) was assessed using a digital infrared laser thermometer at a distance of $50 \mathrm{~cm}$ from the animal. Surface temperature was measured in the forehead (FST), thorax (TST), flank (FLST), and legs (LST). During the study period, the ambient temperature (AT) was significantly higher outside (in the sun) than inside of the facilities (in the shade) $(P<0.05)$. RH was inversely proportional to AT, and was significantly higher inside than outside the facilities $(P<0.05)$. Like AT, THI was significantly higher outside (in the sun) than inside the facilities (in the shade), with significant differences between these locations $(P<$ 0.05). The amplitudes of the differences between the locations were as follows: $3.8^{\circ} \mathrm{C}$ for AT, $6.2 \%$ for RH, and 2.6 for THI. Mean values of rectal and vaginal temperatures were not significantly different from each other independent of lactation cycle stage, and were almost always significantly higher than the measured surface temperatures $(P<0.05)$. The maximum values obtained for each lactation cycle stage in this study were higher when compared to the mean values, showing that they are more representative of the occurrence of heat stress. Correlations between internal temperatures (RT and VT) and surface temperatures (TSF, TST, TSFL, and TSP) were weak and non-significant. ST values exhibited mostly weak, non-significant correlations, with the exception of FST with FLST and LST, which had moderate, significant correlations, as shown by the following coefficient factors: FST x FLST, 0.34; LST x FST, 0.415; and LST x FLST, 0.37.

Discussion: A temperature of $34^{\circ} \mathrm{C}$ with $\mathrm{RH}$ ranging from $46 \%$ to $80 \%$ (i.e., a THI between 83 and 89 ) has been reported to have a significant thermal impact on dairy Brown Swiss cows; the THI values found in the present experiment were close to those. Body temperatures exhibited significant variations depending on the lactation cycle stage of the cows. Lactation concomitant with pregnancy significantly increases internal temperatures (RT and VT) in DP and NPL cows. This finding may be explained by the fact that pregnancy concomitant with lactation accelerates the metabolism, which results in higher food intake and increased production of body heat with consequent increase in internal body temperature. The maximum values of internal body temperatures (RT and TV) at all stages of the lactation cycle were higher than their corresponding average values, which indicates that some cows exhibited, at given moments, hyperthermia.
\end{abstract}

Keywords: body temperature, heat stress, environment, ruminant.

Received: 28 March 2017

Accepted: 7 August 2017

Published: 3 September 2017

${ }^{1}$ Programa de Pós-graduação em Ciências Veterinárias (PPGCV), Universidade Estadual do Ceará (UECE), Fortaleza, CE, Brazil. ${ }^{2}$ Laboratório de Reprodução Animal, Universidade Federal do Ceará (UFC), Fortaleza, CE. ${ }^{3}$ Universidade Federal do Vale do Rio São Francisco (UNIVASF), Petrolina, PE, Brazil. ${ }^{4}$ Universidade Federal do Cariri (UFCA), Crato, CE. ${ }^{5}$ Universidade Luso Brasileira (UNILAB), Redenção, CE. CORRESPONDENCE: A.A. Araújo [aaavet55@ gmail.com - Tel.: +55 (85) 8882-03110]. Faculdade de Veterinária, Universidade Estadual do Ceará (UECE). Av. Dr. Silas Munguba n. 1700. Campus do Itaperi. CEP 60.714.903 Fortaleza, CE, Brazil. 


\section{INTRODUCTION}

The skin plays a key role in body heat dissipation, since there is a constant exchange of heat between the body and the environment. Body temperature is dependent not only on environmental factors such as temperature and humidity, but also on physiological characteristics such as vascularization and evaporation of sweat [29]. Thus, the external surface of the body constitutes a boundary between the body and the environment, and allows the conduction of heat from the internal medium of the body to the body surface, where it can be transferred to the environment [29].

Strong and significant correlation between vaginal temperature (VT) and rectal temperature (RT) have been found in cows at different reproductive stages as observed in pregnant cows [11], cyclic cows [19], and beef heifers, which indicates that such correlation can be used to evaluate animals with hyperthermia due to a disease or occurrence of heat stress [5].

The body surface temperature is an indicator of heat absorption by the animal during thermogenesis and heat loss during thermolysis, which may influence the internal body temperatures in cows at different reproductive and productive status [20,21]; in this context, it remains unknown whether surface temperature (ST) correlates with VT and RT.

Thus, this study aimed to evaluate the occurrence of heat stress in Brown Swiss cows reared in northeastern Brazil and, also, determine whether internal body temperatures (RT and VT) correlate with ST.

\section{MATERIALS AND METHODS}

\section{Location of the experiment}

This study was conducted at the Experimental Farm Vale do Curu (FEVC), which belongs to the Federal University of Ceará (UFC), in the municipality of Pentecoste, state of Ceará, Brazil. FEVC is located in an area with semi-arid climate, between $3^{\circ} 45^{\prime}$ and $3^{\circ} 50^{\prime}$ south latitude and $39^{\circ} 15^{\prime}$ and $39^{\circ} 30^{\prime}$ 'west longitude, has an average altitude of $47 \mathrm{~m}$, and an average rainfall of $818 \mathrm{~mm}$. The climate in that area is classified by the Köppen method as BSw'h', semi-arid with irregular rainfall. This study took place during the hottest period of the year (dry period), in the months of September, October, and November 2015.
Animals

Brown Swiss cows $(n=28)$ at three stages of the lactation cycle were used in this study: 10 nonpregant lactating (NPL) cows, 8 dry pregnant (DP) cows, and 10 pregnant lactating (PL) cows. These animals were between the second and third calvings, weighed between 346 and $720 \mathrm{~kg}$, and had ages between 2 and 13 years.

The cows were maintained in semi-intensive system: in the morning, they were fed natural pasture, which was complemented with concentrated feed after returning from the field; in the afternoon, they were fed elephant grass (Pennisetum purpureum) supplemented with concentrated feed based on corn, soybeans, and wheat.

All animals received diets that met their energy requirements for pregnancy and lactation according to the guidelines of the National Research Council (NRC, 2001) for adult animals. The animals were maintained in stalls according to their lactation cycle stage, where they received mineral salt and water ad libitum.

\section{Evaluation of environmental variables}

During the experimental period, air temperature (AT) and relative humidity $(\mathrm{RH})$ at the experiment site were measured using a digital thermohygrometer ${ }^{1}$. Environmental comfort was estimated using the temperature-humidity index (THI), which was calculated according to methodology described by Thom [31], using the formula THI $=0.8 \times \mathrm{T}+(\mathrm{RH} / 100) \times(\mathrm{T}$ -14.4) + 46.4, where $\mathrm{T}=$ air temperature $\left({ }^{\circ} \mathrm{C}\right)$ and $\mathrm{RH}$ $=$ relative humidity $(\%)$.

\section{Evaluation of physiological variables}

The rectal temperature (RT), vaginal temperature (VT) and surface temperature (ST) of the cows were measured after returning from pasture. The animals were evaluated during the second milking, in the afternoon, at 1:00 p.m., when the ambient temperature (AT) reached its maximum value. DP cows were placed in a squeeze chute to minimize stress. Lactating cows remained in the barn to be milked and, after milking, body temperatures were assessed.

For the assessment of RT and VT, two digital clinical thermometers (TS-101PM) ${ }^{2}$, one inserted in the vagina and the other in the rectum, were used simultaneously to minimize the stress caused by internal body temperature measurement. The thermometer was inserted $7 \mathrm{~cm}$ into the rectum and vagina. 
Surface temperature (ST) was assessed using a digital infrared laser thermometer $(\mathrm{DT}-8867 \mathrm{H})^{3}$ at a distance of $50 \mathrm{~cm}$ from the animal. ST was measured on the forehead (FST), thorax (TST), flank (FLST), and legs (LST). Environmental and physiological data were collected at the same time, once a week, from September to November 2015, totaling 10 data collection sessions.

\section{Statistical analysis}

Statistical analyses were performed using SYSTAT 13 software (USA). The experiment was conducted with a completely randomized design, and data were tested for normality using the Shapiro-Wilk test. Once the homoscedasticity of the data was verified, the means were compared using the Tukey's test at a significance level of 5\%. The correlations between the temperatures were checked using Pearson correlation at a significance level of $5 \%$.

\section{RESULTS}

Climatic data and temperature-humidity index (THI) values are shown in Table 1. During the study period, the ambient temperature (AT) was significantly higher outside (in the sun) than inside the facilities (in the shade) $[P<0.05]$, while the relative humidity $(\mathrm{RH})$ was inversely proportional to AT values, and was significantly higher inside than outside the facilities $(P<0.05)$.

Like AT, THI was significantly higher outside (in the sun) than inside the facilities (in the shade), with significant differences between these locations $(P<0.05)$. The amplitudes of the differences between these locations were as follows: $3.8^{\circ} \mathrm{C}$ for AT, $6.2 \%$ for $\mathrm{RH}$, and 2.6 for THI.
Data on body temperatures obtained in this study (Table 2) show that the mean values of internal (RT and VT) and surface (FST, TST, FLTS, and LTS) temperatures of pregnant lactating (PL) cows were higher than those found for nonpregnant lactating (NPL) and dry pregnant (DP) cows, except for the mean surface temperature (Mean ST). Mean ST in PL cows was lower than in DP cows and higher than in NPL cows, with no significant difference between the values $(P<0.05)$.

Mean values of rectal and vaginal temperatures did not differ significantly from each other independent of the lactation cycle stage, and were almost always significantly higher than the measured surface temperatures $(P<0.05)$. Surface temperatures varied little and exhibited no significant statistical difference $(P>0.05)$ between the evaluated body areas (Table 2$)$. The maximum values obtained in this study for each lactation cycle stage were higher than their respective mean values, showing that they are more representative of the occurrence of heat stress. Table 3 presents the results of Pearson correlations between body temperature values. RT and VT exhibited a strong positive correlation $(r=0.812 ; P<0.05)$. Correlations between internal (RT and VT) and surface temperatures (TSF, TST, TSFL, and TSP) were weak and non-significant. Surface temperature values exhibited mostly weak, non-significant correlations, with the exception of FST with FLST and LST, which had moderate, significant correlations, as demonstrated by the following coefficient factors: FST x FLST, 0.34; LST x FST, 0.415; and LST x FLST, 0.37 .

Table 1. Means \pm standard errors of climatic parameters: air temperature (AT), relative humidity (RH) and temperature and humidity index (THI) during the hot and dry period, in semi-arid climate in the state of Ceará, Brazil.

\begin{tabular}{|c|c|c|c|}
\hline \multirow{2}{*}{ Location } & \multicolumn{3}{|c|}{ Climatic variables } \\
\hline & AT $\left({ }^{\circ} \mathrm{C}\right)$ & $\mathrm{RH}(\%)$ & THI \\
\hline Outside the facility (in the sun) & $40.3 \pm 0.9^{a}$ & $25.3 \pm 2.1^{\mathrm{a}}$ & $85 . \pm 0.8^{\mathrm{a}}$ \\
\hline Inside the facility (in the shade) & $36.5 \pm 0.5^{\mathrm{b}}$ & $31.5 \pm 1.7^{\mathrm{b}}$ & $82.5 \pm 0.5^{\mathrm{b}}$ \\
\hline & $\mathrm{Df}=3.8$ & $\mathrm{Df}=6.2$ & $\mathrm{Df}=2.6$ \\
\hline
\end{tabular}

Different lowercase letters $(\mathrm{a}, \mathrm{b})$ indicate significant differences between values inside and outside the facility, $(P<0.05)$. Df $=$ difference between values in the sun and in the shade. 

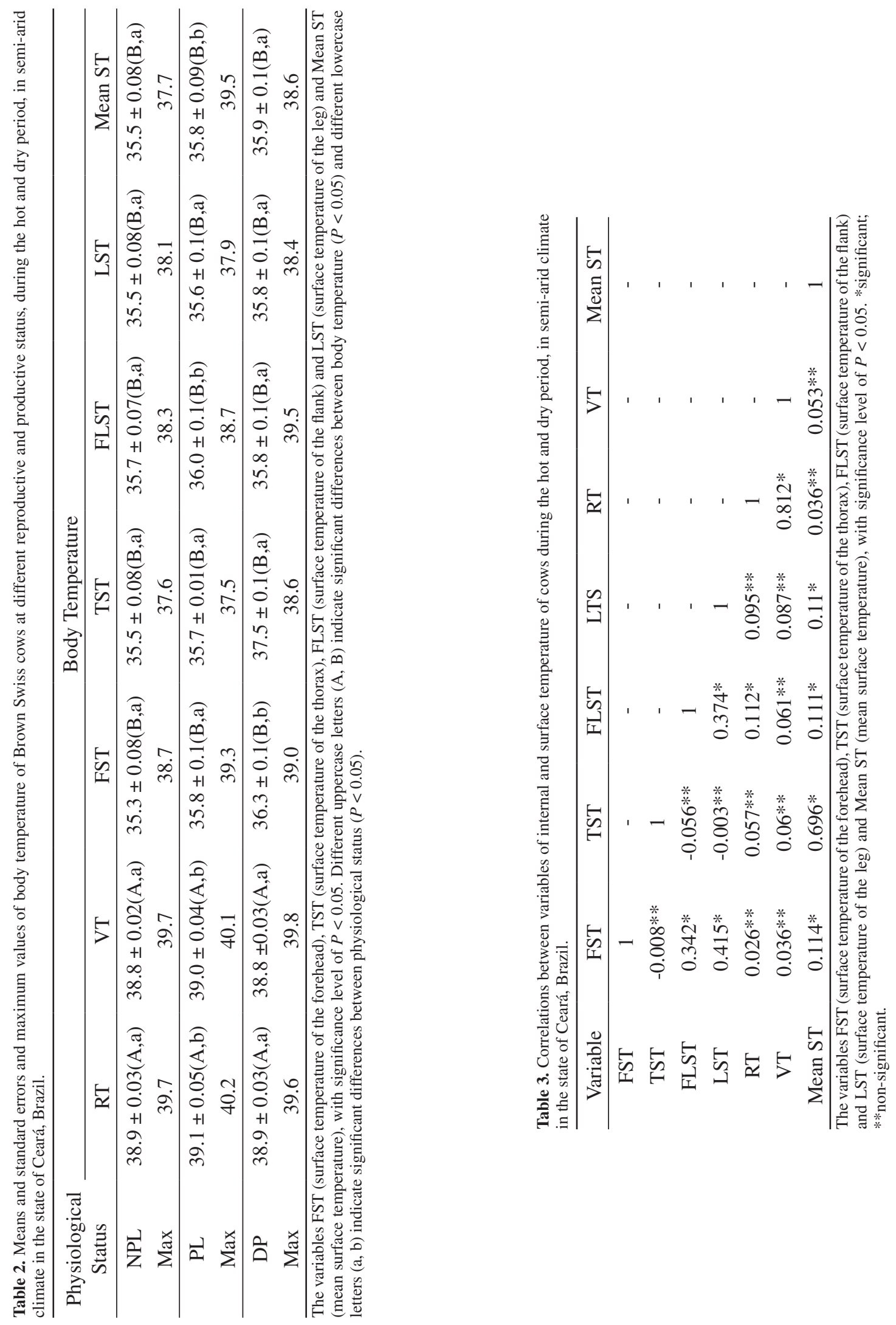


\section{DISCUSSION}

Among the European cattle breeds, the Brown Swiss is one of the most tolerant to heat, with a black skin that absorbs ultraviolet radiation well, and a clear hair that reflects infrared radiation well, characteristics necessary for a good tolerance to heat $[14,26]$. In this context, this breed was chosen to check for correlations between body temperatures (RT, VT, and ST) because it has a homogeneous coating and morphological characteristics that favor adaptation to hot climates.

Temperature and relative humidity exhibited high values both in the sun and in the shade; these parameters affect the temperature-humidity index (THI), which was used to evaluate the environmental comfort and whose values were similar to those previously obtained in the same region [6].

The THI values determined under the environmental conditions present during this study are considered severe to European cattle breed as these values are beyond the thermal comfort zone of these animals [21].

Cows exposed to direct sunlight in an environment where the THI exceeds 72, which is well below the values observed in the present study, are in stressful conditions, particularly if they are high producing dairy cows $[18,25]$.

A temperature of $34^{\circ} \mathrm{C}$ with relative humidity ranging from $46 \%$ to $80 \%$, i.e., a THI ranging from 83 to 89 , has a significant thermal impact on dairy Brown Swiss cows [13]; the THI values found in this study (Table 1) match such a range.

Body temperatures exhibited significant variations depending on the physiological status of the cows. Lactation concomitant with pregnancy significantly increases internal temperatures (RT and VT) in dry pregnant (DP) and nonpregnant lactating (NPL) cows. This finding may be explained by the fact that pregnancy concomitant with lactation accelerates the metabolism, which results in higher food intake and increased production of body heat with consequent increase in internal body temperature.

The maximum values of internal body temperatures (RT and TV) at all stages of the lactation cycle were higher than their corresponding average values, which indicates that some cows exhibited, at given moments, hyperthermia. The maximum body temperature values are more representative of the occurrence of heat stress than mean body temperature values, which indicates that the maximum values are always more reliable [6,21]. A RT above $39 \cdot 2^{\circ} \mathrm{C}$ is indicative of heat stress [1]. In this study, rectal and vaginal temperatures above this value $\left(>39.5^{\circ} \mathrm{C}\right)$ were found in maximum values; this indicates that some Brown Swiss animals have difficulty in regulating internal temperature in semi-arid climate conditions.

The results of this study confirm those reported by Silva et al. [29], according to which maintenance of body temperature occurs by exchange of heat with the environment. Consequently, under low ambient temperatures, the heat is dissipated to the environment in sensible form via a temperature gradient formed between animal and environment. On the other hand, when ambient temperatures are higher than body temperature, as observed in this study, heat exchange between the animal and the environment is difficult.

Accordingly, high ambient temperatures like those observed in this study $\left(36^{\circ} \mathrm{C}\right.$ to $\left.40^{\circ} \mathrm{C}\right)$ reduce heat loss from the body to the environment because there is no favorable heat gradient for efficient thermolysis, which leads to a body temperature above normal physiological limits and results in accumulation of body heat, i.e. thermal stress. The strong correlation between RT and VT found in this study $(r=0.812)$ is in agreement with results from studies on pregnant cows $(r=$ $0.90)$ [11], cyclic cows $(r=0.95)$ [19], and heifers $(r$ $=0.92$ ) [5]. In those studies, the authors reported RT values higher than VT values, and a strong positive correlation between these variables. The strong correlation between RT and VT occurs because the vagina and the rectum are very close to each other, and are separated only by the pelvic fascia [9].

Body surface temperatures are always lower than internal temperatures, and they may vary widely between different parts of the body surface. In this study, the difference between the internal and the surface temperature was around $3.3^{\circ} \mathrm{C}$, confirming the results obtained by Yuri et al. [34], who measured temperatures on the rumps of Holstein cows. Silva [24] reported that temperature is not homogeneous throughout the body and varies according to anatomical region because of differences in the metabolic activity of the various tissues; this observation is valid for both internal and surface temperatures.

Although surface temperatures (ST) are an important parameter in most studies on heat stress, these are influenced by various environmental factors, such 
as ambient temperature, relative humidity, and wind speed, and vary greatly depending on the differences in the body surface areas. The wide temperature variation between surface areas throughout the body occurs because these zones do not share the same extent of physical contact with the environment, which may explain the weak correlations between temperatures measured on them $[8,20]$.

In addition, the weak correlations between ST and internal temperatures (RT and VT) indicate that ST is not reliable for the assessment of heat stress. Therefore, internal temperatures are more accurate than surface temperatures to evaluate heat stress. In this context, Bianca [3] argued that a rectal temperature higher than normal physiological values is indicative of heat stress.

Several studies have used surface temperature to assess heat stress in tropical ruminants such as goats [30], sheep [27], and cattle [4]. However, those studies failed to demonstrate a correlation between internal and surface temperatures, and did not determine normal body surface temperatures for those species.

The difficulty in determining a normal range for surface temperature is probably related to the influence of environmental factors and the variation in coat color as reported by Salles et al. [23], who studied cattle with various coat colors in a semi-arid climate. In general, the color and the morphological characteristics of the coat in cattle directly affect the exchange of sensible heat and the loss of latent heat to the environment [14]. Therefore, the evaluation of surface temperature in various breeds of cattle in different climates must consider environmental and genetic factors besides the specific characteristics of the skin.

\section{CONCLUSION}

The semi-arid climate is not suitable for Brown Swiss cattle because air temperature and relative humidity contribute to form a hostile environment, as shown by the temperature-humidity index values found in this study.

Rectal temperature and vaginal temperature are strongly correlated and are more reliable than surface temperatures for assessing the occurrence of hyperthermia in Brown Swiss cows reared in a semi-arid climate.

\author{
MANUFACTURERS \\ ${ }^{1}$ Incoterm. São Paulo, SP, Brazil. \\ ${ }^{2}$ Techline Comercial Importação e Exportação. São Paulo, SP, Brazil. \\ ${ }^{3} \mathrm{CEM}$ Clean Energy Ministerial. Beijing, China.
}

Funding. This research had logistical support from the Federal University of Ceará (UFC), Brazil.

Ethical approval. This research was approved by Animal Care and Use Committee (CEUA) of the Ceará State University (UECE) (Project Number 2015/3085301).

Declaration of interest. The authors declare that there is no conflict of interest that could be perceived as harmful to the impartiality of the research reported.

\section{REFERENCES}

1 Azevedo M., Mari Pires M.F.A. \& Saturnino H.M. 2005. Estimativa de níveis críticos superiores do índice de temperatura e umidade para vacas leiteiras 1/2, 3/4 e 7/8 Holandês-Zebu em lactação. Revista Brasileira de Zootecnia. 34(6): 2000-2008.

2 Baccari Jr. F. 1987. Stress e estressores. Stress climático. Gado Holandês. 51(138): 11-18.

3 Bianca W. 1961. Heat tolerance in cattle its concepts: measurement and dependence on modify factors. International Journal of Biometeorology. 5(1): 5-30.

4 Barbosa B.R.P., Santos S.A., Abreu U.G.P., Egito A.A., Comastri Filho J.A., Juliano R.S., Paiva S.R. \& McManus C. 2014. Tolerância ao calor em bovinos das raças Nelore branco, Nelore vermelho e Pantaneira. Revista Brasileira Saúde e Produção Animal. 15(4): 854-865.

5 Burdick N.C., Carrol J.A., Dailey J.W., Randel R.D. \& Falkenberg S.M. 2012. Development of a self-contained indwelling vaginal temperature probe for use in cattle. Research Journal of Thermal Biology. 37(3): 39-343.

6 Costa A.N.L., Feitosa J.V., Montezuma Júnior P.A., Souza P.T. \& Araújo A.A. 2014. Hormonal profiles, physiological parameters, and productive and reproductive performances of Girolando cows in the state of Ceará-Brazil. International Journal Biometeorology. 15(4): 484-970.

7 Darcan N., Cedden F. \& Guney O. 2007. Spraying effects on goat welfare in hot and humid climate. American Journal of Animal and Veterinary Sciences. 2(4): 99-103.

8 Ferreira F. 2006. Parâmetros fisiológicos de bovinos cruzados submetidos ao estresse calórico. Arquivo Brasileiro de Medicina Veterinária e Zootecnia. 58(5): 732-738. 
9 Frandson R.D., Wilke W.L. \& Fails A.D. 2005. Anatomia e Fisiologia dos Animais da Fazenda. 6.ed. Rio de Janeiro: Guanabara Koogan, pp.370-392.

10 Head H.H. \& Gulay S.M. 2001. Recentes avanços na nutrição de vacas no período de transição. In: Simpósio sobre Produção de Leite. UFLA. 3.ed. Lavras: SINLEITE, pp.121-137.

11 Hillman P.E., Gebremedhim K.G., Williard S.T., Lee C.N. \& Kennedy A.D. 2009. Continuous measurements of vaginal temperature of female cattle using a data logger in a plastic anchor. Applied Engineering in agriculture. 2(5): 291-296.

12 Hossam El-Sheikh A., Kitahara G.O., Tamura Y., Kobayashi Y., Koichiro H., Torisu S., Hiroshi S., Horii Y., Zaabel S. \& Kamimura S. 2012. Presence of a temperature gradiente among genital tract portions and the termal changes within these portions over the estrus cycle in beef cows. Journal of Reproduction and Development. 59(1): 59-65.

13 Johnson H.D. \& Vanjonack W.J. 1976. Effects of environmental and other stressors on blood hormone patterns in lactating animals. Journal of Dairy Science. 59(9): 1603-1617.

14 Maia S.C., Silva R.G. \& Bertipaglia E.C.A. 2003. Características do pelame de vacas holandesas em ambiente tropical: um estudo genético e adaptativo. Revista Brasileira de Zootecnia. 32(4): 843-853.

15 Monty Junior D.E., Kelly L.M. \& Rice W.R. 1991. Aclimatization of St Coix, Karakul and Ambouillet sheep to intense and dry summer heat. Small Ruminant Research. 4(4): 379-392.

16 Neiva M.N.J., Turco S.N.H., Oliveira S.P.M. \& Moura A.N.A.A. 2004. Efeito do estresse climático sobre os parâmetros produtivos e fisiológicos de ovinos Santa Inês mantidos em confinamento na região litorânea do Nordeste do Brasil. Revista Brasileira de Zootecnia. 3(3): 668-678.

17 Perissinotto M., Moura D.J. \& Cruz V.F. 2009. Conforto térmico de bovinos leiteiros confinados em clima subtropical e mediterrâneo pela análise de parâmetros fisiológicos utilizando a teoria dos conjuntos fuzzy. Revista Ciência Rural. 39(5): 1492-1498.

18 Pires M.F.A., Ferreira A.M. \& Coelho S.G.1999. Estresse calórico em Bovinos de Leite. Caderno Técnico de Veterinária e Zootecnia. 2(9): 23-37.

19 Rajamahendran R., Robinson J., Desbottes S. \& Walton J.S. 1989. Temporal relationships among estrus, body temperature, milk yield, progesterone and luteinizing hormone levels, and ovulation in dairy cows. Theriogenology. 3(1): 1173-1182.

20 Robinson N.E. 2004. Homeostase e Termorregulação. In: Cunningham J.G. (Ed).Tratado de Fisiologia Veterinária. 3.ed. Rio de Janeiro: Guanabara Koogan, pp.550-561.

21 Rocha D.R., Araújo A.A., Moura A.A.A.N. \& Sales M.G.F. 2008. Avaliação de estresse térmico em vacas leiteiras mestiças (Bos taurus x Bos indicus) durante os períodos chuvoso e seco no Estado do Ceará. In: $45^{\circ}$ Reunião Anual da Sociedade Brasileira de Zootecnia (Lavras, Brazil). 3p.

22 Rocha D.R., Salles M.G.F., Moura A.A.A.N. \& Araújo A.A. 2012. Índices de tolerância ao calor de vacas leiteiras no período chuvoso e seco no Ceará. Revista Acadêmica Ciências Agrárias e Ambientais. 10(4): 335-343.

23 Salles M.G.F., Silva Junior F.A.P., Pereira Pinto A.B., Rodrigues I.C.S., Viana Neto A.M., Rocha D.R. \& Araújo A.A. 2015. Termotolerância de vacas mestiças segundo a cor do pelame no período seco do semiárido cearense. In: $25^{\circ}$ Congresso Brasileiro de zootecnia (Fortaleza, Brazil). 3p.

24 Silva R.G. 2000. Introdução à bioclimatologia animal. São Paulo: Editora: Nobel, 286p.

25 Silva I.J.O., Pandorfi H., Acararo Jr. E., Piedade S. \& Moura D.J. 2002. Efeitos da climatização do curral de espera na produção de leite de vacas holandesas. Revista Brasileira de Zootecnia. 31(20): 36-42.

26 Silva R.G., La Scala Jr. N. \& Tonhati H. 2003. Radiative properties of the body surface of cattle and others animals. Transaction of ASAE. 4(6): 913-918.

27 Silva R.G. \& Sterling J.M.C. 2003. Evaporação Cutânea e Respiratória em Ovinos sob Altas Temperaturas Ambientes. Revista Brasileira de Zootecnia. 32(6 Suppl 2): 1956-1961.

28 Silva E.M.N., Souza B.B., Silva G.A., Cezar M.F., Souza W.H., Benício T.M.A. \& Freitas M.M.S. 2006. Avaliação da adaptabilidade de caprinos exóticos e nativos no semi-árido paraibano. Ciência e Agrotecnologia. 30(1): 516-521.

29 Silva J.J.F.C., Torquato J.L., Sá Filho G.F., Souza Jr. J.B.F. \& Costa L.L.M. 2013. Evaporação cutânea e respostas fisiológicas de caprinos Canindé em ambiente equatorial semiárido. Journal Animal Behavior and Biometeorology. 6(1): 13-16. 
30 Souza B.B., Souza E.D., Silva R.M.N., Cezar M.F., Santos J.R.S. \& Silva G.A. 2008. Respostas fisiológicas de caprinos de diferentes grupos genéticos no semi-árido paraibano. Ciência e Agrotecnologia. 32(1): 314-320.

31 Thom E.C. 1958. Cooling degrees: day air conditioning, heating and ventilating. Transactions of the ASAE. 55(7): 65-72.

32 Vickers A., Von Keyserlingk M.A.G., Veira D.M., Weary D.M. \& Heuwieser W. 2010. Technical note: Comparison of rectal and vaginal temperatures in lactating dairy cows. Journal of Dairy Science. 9(3): 5246-5251.

33 West J.W. 1999. Nutritional strategies for managing the heat-stressed dairy cow. Journal of Dairy Science. 8(Suppl 2): 21-35.

34 Yuri R. Montanholi., Nicholas E., Odongo Kendall C. \& Swanson S. 2008. Application of infrared thermography as an indicator of heat and methane production and its use in the study of skin temperature in response to physiological events in dairycattle (Bos taurus). Journal of Thermal Biology. 3(3): 468-475. 